\title{
The Politics of Water in South Asia
}

\author{
Transforming Cultures eJournal, \\ Vol. 1 No. 2, June 2006 \\ http://epress.lib.uts.edu.au/journals/TfC
}

\section{Douglas Hill \\ Department of Geography University of Otago}

\section{Introduction}

Disputes over water are central to the political economy of development in South Asia. This paper looks at the way that the allocation of water is mediated by different kinds of state-society relations in India, Bangladesh and Pakistan by examining common property resource management issues from three different spatial scales: international, intra-national and intra-community. By doing so, we can begin to appreciate the complexity of problems in the management of water and the likely trends throughout the region. We do this by examining the contestations over rivers, canals, dams and groundwater. The role of agricultural change in contributing to the intensification of water usage in the rural areas is emphasised. Despite some diversification into non-agricultural activities in the rural areas and limited industrialisation in the urban areas, 70-80 percent of the region's fresh water is utilised for agriculture at the present juncture. ${ }^{1}$

At the broadest level, the management and utilisation of water resources in the riparian regions of South Asia is pivotal to the geopolitics of the region. Ongoing trans-border disagreements related to rivers and canals frame the relationship between the countries of both the Indus River Basin (India and Pakistan) and the Ganges-Brahmaputra-Meghna River Basin (India, Bangladesh and Nepal; hereafter referred to as the Ganges Basin). These resources have been regulated to some extent through bilateral treaties between the relevant nations in each basin but suspicions between the nation-states remain.

\footnotetext{
${ }^{1}$ K. Haq (2003) Human Development in South Asia 2002: Agriculture and Rural Development, Mahub ul Haq Human Development Centre, Oxford University Press.
} 
In addition to these international conflicts, there are also contestations occurring at different spatial scales within each nation. The development process is different in each country and this has impacted upon the way that these domestic disputes over water resource usage are framed. The structural and political characteristics of each economy are examined, which includes an examination of different agrarian class structures and their relationship to the state and the urban classes.

Intra-national disputes are examined in two interrelated senses in this paper. The first sense is the competition between provincial states within a nation over water resources. Dams are often viewed as emblematic of the pattern of development in each of the countries. The second sense of intra-national disputes over water is the social cleavages affecting the division of resources within each society. These intra-national disputes take different forms in each of the countries examined, depending on the balance of state-society relations.

The last level of analysis is intra-community. Local clashes over the management of water resources, particularly groundwater, are an increasing trend in each of these countries. Indeed unequal access to water remains one of the most significant factors in perpetuating uneven development, resource scarcity and poverty. These distributional conflicts have geographical, class and gender dimensions. The intra-community scale is undoubtedly of growing importance, with greater demands on water at the local level.

The paper notes that at each of these levels, there are emerging coordination problems, which will present ecological and social dilemmas in the future. Significantly, however, the political strength of emergent movements from the rural areas mitigate against an appropriate response to this.

\section{Dimensions of the Indus and Ganges River Basins}

The two major river basins in the northern parts of South Asia are the Ganges Basin and the Indus Basin. These respectively cover the eastern and western sections of the subcontinent. The significant rivers of these two basins - the Indus, Ganges, and Brahmaputra - all originate near Mount Kailash range in Tibet. Thereafter, the Indus flows to the west, eventually running into the Arabian Sea. In contrast, the Ganges and Brahmaputra flow 
down to the south and east respectively. Both of these latter rivers eventually link together and discharge in the Bay of Bengal.

Both of these basins are historically significant as the basis of great civilisations. The Ganges Basin is one of the largest in the world, covering a population of at least 600 million people. ${ }^{2}$ Nevertheless, it is also comparatively one of the most under-utilised systems in the world. Its catchment area includes five countries (Bangladesh, Bhutan, India, Nepal and China), although the majority of the downstream sections of the basin are within Bangladesh and India. The Gangetic delta is also fed by the Indian states of Uttaranchal (part of Uttar Pradesh until 2000) and Sikkim (an independent nation-state until 1973) as well as the independent nation-states of Nepal and Bhutan.

The Indus Basin is ostensibly a much simpler geopolitical situation than the Ganges Basin, since it only involves two countries. In Pakistan, the alluvial plains of the Indus basin cover approximately 25 percent of the land area of Pakistan, with Punjab and Sindh the most agriculturally important provinces. ${ }^{3}$ In India, the basin includes only 9.8 percent of the total geographical area of the country. On the Indian side, the upper part of basin includes the mountainous states of Jammu \& Kashmir and Himachal Pradesh. The lower part of the basin includes the plains area of the fertile and productive states of Punjab and Haryana; the semi-arid Rajasthan; and the Union Territory of Chandigarh.

\section{International Contestations over water: India-Pakistan and India- Bangladesh}

Given the importance of these basins, it is unsurprising that boundaries drawn across them thus dividing their resources - have been the source of significant controversy. In this sense, the region's defining event was the partition of British India at Independence in 1947. After war-weary Britain acceded to demands for the Independence of its former colonies, the two basins were divided between India and two geographically separate halves of Pakistan. East

\footnotetext{
${ }^{2}$ For a full exposition of the features of the Ganges basin see Bandyopadhyay, J. (1995) "Water Management in the Ganges-Brahmaputra Basin: Emerging Challenges for the $21^{\text {st }}$ Century", Water Resources Development, 11(4): 411-442.

${ }^{3}$ World Commission on Dams (2000) Pakistan: The Tarbela Dam and Indus River Basin Final Paper Executive Summary, November $2000<\mathrm{http}: / / w w w . d a m s . o r g / k b a s e /$ studies/pk/pk_exec.htm>.
} 
Pakistan, later to become Bangladesh, was surrounded by upper riparian parts of India's North-eastern states, while the delta flowed into the Bay of Bengal in both (Pakistani) East and (Indian) West Bengal. In the western part of the sub-continent, the resulting partition of India and Pakistan was achieved by drawing a boundary across the Indus Basin, so that the upper riparian territory was claimed by India, while the Indus flows into the sea entirely within Pakistani territory.

Up until partition, there had been a far greater investment in the infrastructure of the western part of British India, and so the Indus basin has historically been an important component of the agricultural systems of both western India and west Pakistan. After the canal developments in the $1860 \mathrm{~s}$, an enormous population expansion occurred in the (then undivided) Punjab and the region continued to benefit from the building of canals in the nineteenth and early twentieth century. The centralisation of the canal system was important for the political structures it helped create and then perpetuate, with the colonial

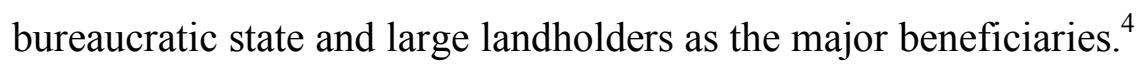

The boundaries drawn up at partition left Pakistan, as the lower riparian, in a vulnerable position, since the irrigation canal supplies in Punjab, Pakistan's most fertile area, had their source in Indian territory. In April 1948 India closed the canals on the eastern rivers of Ravi and Sutlej, only agreeing to reopen them after the Inter-Dominion Agreement of May 1948, where it claimed the entire water of the eastern rivers. ${ }^{5}$ This was only an interim agreement and the Indus Water Treaty (IWT) was finally negotiated between India and Pakistan in 1960. This gave India the eastern rivers (Ravi, Beas and Sutlej) and Pakistan the western rivers (Jhelum, Chenab and the Indus itself). Since India was the upper riparian country for even these latter rivers, there were some restrictions placed on its capacity to modify the flow of these rivers.

There is a commonly held belief that the Indus Water Treaty is a significant example of bilateral cooperation between two nations that otherwise remain largely mired in seemingly

\footnotetext{
${ }^{4}$ I. Ali (2004) "Historical Impacts on Political Economy in Pakistan" Asian Journal of Management Cases, $1(2)$.

${ }^{5}$ H. Gazdar (2005) "Baglihar and Politics of Water” Economic and Political Weekly, Feb. 26.
} 
intractable conflicts. Advocates of this position note that the Treaty was not abrogated even during the 1965 war between the two nations. However, this largely ignores the historical contingencies that were so important in constraining Pakistan's initial scope of action. ${ }^{6}$ The agreement between India and Pakistan was largely brokered with the assistance of the World Bank and although there was the appearance of concession, India was able to achieve its objectives.

The Indus Basin Project was the compensation Pakistan received for its loss of access to the eastern rivers. This led to the building of new storage reservoirs, barrages and inter-river link canals and the remodelling of three existing link canals. ${ }^{7}$ The most visible results included dams at Tarbela (the world's largest earth filled dam), Mangla and Chashma. ${ }^{8}$ The main purpose of this infrastructure was irrigation, with power as a secondary objective. The Indus Basin Project was financed via the Indus Basin Development Fund (IBDF), which included contributions from the World Bank bilateral donors and a fixed contribution from India. $^{9}$

In recognition of the fact that India was the upper riparian country for the western rivers which were allocated to Pakistani, there are restrictions placed on its capacity to modify the flow of these rivers, so that Pakistan's lower riparian rights are not impeded. One of these provisions is that India is able to build storage facilities on rivers that flow into Pakistan only if these are of limited capacity. This provision has consistently been tested by India as it has sought to expand the number of projects it has in the upper reaches of the western rivers.

In recent months these provisions have been tested as another dispute has arisen over the building of the Baglihar barrage on the Chenab River in the Indian state of Jammu and

\footnotetext{
${ }^{6}$ Ibid.

${ }^{7}$ WCD Case Studies (2000) Tarbela Dam and related aspects of the Indus River Basin Pakistan Final Draft Report (World Commission on Dams), p. iii.

${ }^{8}$ K. Haq (2003:59).

${ }^{9}$ World Commission on Dams and Asianics (1999) Review of the Performance and Development Effectiveness of Tarbela Dam in The Context of the Indua Basin Scoping Report (Islamabad and South Africa), p. 10.
} 
Kashmir. The barrage, which began to be constructed in 1999 and is scheduled to be finished in 2007, is contentious because Pakistan believes that it is in violation of the IWT and other treaties laying out India's international obligations, since the Chenab is supposed to be primarily for use by Pakistan. ${ }^{10}$ Pakistan asked for the intervention of the World Bank to appoint a neutral arbiter, who was unable to broker a solution satisfactory to both parties despite repeated meetings. ${ }^{11}$ The issue continues to be a background tension in the evolving relationship between India and Pakistan. Despite the objections of Pakistan and contention over the legality or otherwise of the project, it is clear that India intends to complete the barrage. $^{12}$

\section{India-Bangladesh}

Despite the fact that there are several countries involved in the Ganges basin, the management of these water resources has been negotiated bilaterally, with India negotiating with Nepal and Bangladesh as separate parties. Here, geopolitical considerations limiting the cooperation between countries have historically been at least as important in limiting the usage of the water resources as the hydrological properties of the rivers within this basin. ${ }^{13}$ Although Bangladesh and India share 54 common rivers, the main dispute between India and Pakistan/Bangladesh in the Ganges Basin has been over the building of the Farakka barrage, which diverts water from the Ganges into the Hoogli river on the Indian side of the border. The Farakka barrage was first conceived of in 1950 by then Prime Minister Nehru, who supposedly regarded the building of the barrage as having few illeffects on Bangladesh (then East Pakistan). India's rationale then, as now, was that it

\footnotetext{
${ }^{10}$ Pakistan maintains that the building of the barrage is in contravention of the Indus Water Treaty and India's international obligations under the Convention on the Protection and Use of Transboundary Watercourses and International Lakes signed at Helsinki in March 1992.

11 "Baglihar project talks fail; Pak threatens to move World Bank" The Hindu Businessline, Jan 08, 2005; "World Bank may help resolve Baglihar row", The Hindu Businessline, March 09, 2005. For a legal background see A.G. Noorani (2002) “A treaty to keep", Frontline19 (08) April 13 - 26.

${ }^{12}$ Thus, while there were early indications that the Baglihar may not be used to full potential the Indian government has renewed its commitment to the project in its 2006-07 Budget, which includes a Rs. 2.3 billion outlay for Baglihar as part of a more broad ranging allocation aimed at enhancing power development in the troubled Indian state of Jammu \& Kashmir. On this see "Is Baglihar turning into a white elephant?", Hindustan Times 5 Feb. 2006 and "Kashmir gets special aid for development, power" Hindustan Times 28 February 2006.

${ }^{13}$ Brichieri-Colombi, S. \& R.W. Bradnock (2003) "Geopolitics, water and development in South Asia: cooperative development in the Ganges-Brahmaputra delta" The Geographical Journal, March.
} 
needed diversion of water to the Hoogli river in order to flush out siltation and keep the Port of Calcutta operational. ${ }^{14}$

When Pakistan drew India's attention to the reports of these plans to build the barrage, in October 1951, India dismissed the claims by saying that the possibility of building a barrage at Farakka was only under investigation. Meetings on the issue began between the two countries in 1960, with India officially beginning construction in January 1961. Meetings continued until 1970 without any real progress being achieved. A measure of India's attitude towards the sharing of these waters is evidenced by the fact that it was not until 1970 that it was acknowledged that usage of the Ganges was an international issue.

In 1970 India had completed construction of the barrage but still had some technical problems. Talks were suspended when the East Bengali political forces under the Awami League began agitations that would escalate into Bangladesh's War of Independence.

Bangladesh's independence from Pakistan, with considerable assistance from India, signalled an era of goodwill between India and Bangladesh, with the signing of the Treaty of Friendship and Cooperation, which was to be valid for 25 years. In May 1972 the two countries established a Joint Rivers Commission, which would be the final arbiter of matters if the process fails through the negotiations of lower levels, such as secretaries.

However, the ambit of the Commission specifically excluded the issue of Ganges development, which was to be taken at the Prime Ministerial level. It was not until May 1974 that the two Prime Ministers met and agreed to try to find a mutually agreeable solution, which was to be achieved by turning the issue over to the Joint Rivers Commission. In April 1975 both sides agreed to a trial period of operation of the barrage. When this trial period ended, after 41 days, India continued to divert water without seeking fresh permission from any level of Bangladeshi government. Thereafter, the continuing round of meetings achieved little, until Bangladesh formally lodged a complaint with the United Nations in 1976. The United Nations urges the two parties to find a solution. The Ganges Water Agreement, signed in November 1977, was for a period of 5 years. When

\footnotetext{
${ }^{14}$ Hossain, I., (1998) "Bangladesh-India Relations: The Ganges Water-Sharing Treaty and Beyond” Asian Affairs, 25(4): 131.
} 
this time elapsed, no new agreement was reached until 1985, when a Memorandum of Understanding for sharing water in the lean season. This was valid until 1988 and after this time no new agreement was signed.

It would not be until December 1996 that the Ganges Water Sharing Treaty would finally be signed. The main provisions of the Treaty concerned a formula for the distribution of water during the lean season between January 1 and March 31 each year. Bangladesh was assured a guaranteed flow of 35,000 cusec. The agreement should guarantee an adequate flow of water to the south-western districts of Bangladesh, where many of the country's agriculture, aquaculture and industries are located, and prevent salination of the mangrove delta, the Sunderbans.

Despite these agreements, the water-sharing arrangements have remained controversial. This is particularly the case in Bangladesh, where these bilateral agreements have become a rallying point for nationalist campaigns against India, particularly by the Bangladesh Nationalist Party (BNP). The Hindu populist Bharatiya Janata Party (BJP) has conducted similar campaigns in India over what it sees as the compromises of national interest. ${ }^{15}$ Significantly, while both of these parties have been vociferous in their demands against current water-sharing arrangements when in opposition, when in government, neither have they shown any interest in abrogating the Treaty.

The critics of the current arrangements in Bangladesh view the terms of water-sharing as inequitable and symptomatic of the broader relationship between the two countries. From this perspective, India had aggressively asserted its own interest to the detriment of Bangladesh, to the extent that almost every negative development in rural Bangladesh is linked to the Farakka barrage. The Indian perspective, in contrast, asserts that Bangladesh has been unwilling to compromise and has expected that its share of water resources will always remain undiminished.

\footnotetext{
${ }^{15}$ D. Wright, (2002) “The BJP and Bangladesh” South Asia vol. XXV: 381-393; S. Anwar (1996)

"Opposition slams Bangladesh water deal with India" Reuters News $14^{\text {th }}$ December.
} 
After the division of resources had been settled, the issue then moved to strategies to augment storage, since it was recognised that the current arrangements could not guarantee sufficient water for both sides. Bangladesh's solution was to involve Nepal, since its vast, snow-fed seasonal resources were seen as largely wasted for want of appropriate storage facilities. However, India consistently refused to involve Nepal. Indeed, water-sharing negotiations are conspicuously absent from discussions at SAARC (South Asian Association for Regional Cooperation), the regional body that would otherwise have seemed an obvious forum for such multilateral coordination.

\section{Intra-national contestations: Political economy of Development in India, Pakistan and Bangladesh}

Discussion about bilateral issues between countries can only take us so far in understanding the complexity of issues inherent in water-sharing, since the compulsions for these international disputes have domestic roots embedded in the prevailing structure of development. In all the countries examined, internal political forces conditioning the nature of the development strategy have been important in the usage of water. There are strong historical reasons for this.

In India, the state at Independence was not strong enough to undertake planned industrialisation and so assisted the domestic bourgeoisie via a mixed economy. This strategy politically necessitated an alliance with rich farmers, who dominated provinciallevel politics. The various class interests of these dominant groups, along with those who had participated in the mass-movement for Independence, were accommodated within the Indian National Congress. The strength of the large landholders conditioned the shape of post-Independence development policy. In this sense, land reform, as a central component of an alternative agricultural strategy, was never seriously considered, despite rhetorical commitment to the contrary. ${ }^{16}$ The resultant 'passive revolution' continues to condition the contours of India's development strategy. ${ }^{17}$ Pranab Bardhan has captured the dominant

\footnotetext{
${ }^{16}$ S. Corbridge \& J. Harriss (2000) Reinventing India: Liberalization, Hindu Nationalism and Popular Democracy. Cambridge: Polity Press.

${ }^{17}$ For examples of the application of the passive revolution framework to India see A. Chakrabarti \& S. Cullenberg (2003) Transition and development in India. New York and London: Routledge; Kaviraj, S.,
} 
consensus on the class biases of the development process with his description of the three 'dominant proprietary classes' of industrialists, rich farmers and intelligentsia or bureaucracy. ${ }^{18}$

Issues of federalism have complicated these matters. The initial division of powers in the Constitution pertaining to water disputes envisaged a two fold approach, which reflects the division of powers between Centre and State in the Union and State lists. Firstly, the Centre was given the power to develop trans-boundary waters. Secondly, each State was given the power to develop waters within its boundaries. ${ }^{19}$ Since this time distribution of water resources has become an important area of political contestation between different states. The Inter State Water Disputes Act (1956), amended in 2002, provides a mechanism for the formation of a tribunal to resolve any conflicts arising from the sharing of water. Thus far such a tribunal has been formed to settle disputes on five occasions. These are the Godavari Water Disputes Tribunal (April 1969); the Krishna Water Disputes Tribunal (April 1969); the Narmada Water Disputes Tribunal (Oct. 1969); the Ravi and Beas Waters Tribunal (April 1986) and the Cauvery Water Disputes Tribunal (1991). These conflicts have been significant in the political agenda of regional parties in the contending states. ${ }^{20}$

\section{Pakistan}

The undivided Pakistan was mainly constituted from a hinterland that had provided agricultural raw materials for mills in India (jute for Calcutta in the case of East Bengal; cotton for Bombay in the case of West Pakistan). It had comparatively low levels of industrialisation and as such there was not an indigenous bourgeoisie that could assist the state with development in the way that it could in India. Much of the entrepreneurial and

(1998) 'A Critique of the Passive Revolution' in P. Chatterjee (ed.) State and Politics in India, Delhi: Oxford University Press, pp. 45-87.

${ }^{18}$ P. Bardhan (1984) The Political Economy of Development in India, Delhi: Oxford University Press.

${ }^{19}$ These are Entry 56 of the Union list and Entry 17 of the State list respectively.

${ }^{20}$ Godavari Water Disputes Tribunal was formed to adjudicate between Maharashtra, Madhya Pradesh, Karnataka, Andhra Pradesh and Orissa. The Krishna Water Disputes Tribunal was between Maharashtra, Karnataka and Andhra Pradesh. The Narmada Water Disputes Tribunal was between Madhya Pradesh, Gujarat, Maharashtra and Rajasthan. The Ravi and Beas Waters Tribunal was between Punjab, Haryana and Rajasthan and the Cauvery Water Disputes Tribunal between Karnataka and Tamil Nadu. 
professional classes emigrated to India at partition. ${ }^{21}$ The major political force in Pakistan was the (West Pakistani) agrarian elite. This class had actively cooperated with the British in the colonial period, with the Punjab's canal economy strengthening their position. As such, while there were subsequently attempts to create an industrial class, this was not at the expense of the rural elites. Émigré Gujarati trading classes were relied on by the new state to create a commercial and industrial base. By 1968, just twenty-two families controlled the vast majority of the Pakistan's economy. Investment patterns and industrial licensing reflected this bias, with investment in many sectors in Karachi exceeding that for the whole of East Pakistan! ${ }^{22}$

The military-bureaucratic oligopoly that has controlled the state in Pakistan since partition, in various guises, has functioned to the advantage of the Punjabi landlord class. Wealth accumulation for the industrial classes has been built on patronage from the Pakistani civil service. However, political power remains with the military and bureaucracy, who were recruited from the traditional landed gentry and aristocracy. ${ }^{23}$ In the post-East Pakistan phase, the Pakistani state has continued to intervene to assist the rural elite. Measures under Zulfikar Ali Bhutto included the formation of public sector trading companies to protect export crops and the nationalisation of agribusiness sectors, which was decisive in the 1977 election. ${ }^{24}$ There also continues to be strong antagonism by the provinces of Baluchistan, NWFP and Sindh over what is seen as a development process centred on the interest on Punjab.

Provincial rivalry over the division of the water in the Indus basin was an issue of considerable debate as early as 1920 , with Sindh objecting to projects involving the Sutlej river valley and Sukkur barrage, which were proposed by Punjab. The then Central Government of India attempted to resolve these disputes, either through Commissions or negotiation between the provinces. The earliest attempt, the Anderson Commission (1935),

\footnotetext{
${ }^{21}$ I. Ali (2004:129-146).

${ }^{22}$ R. Nations (1971) “The Economic Structure of Pakistan: Class and Colony” New Left Review, No. 68, JulyAugust.

${ }^{23}$ Ibid.

${ }^{24}$ I. Ali (2005) “Business, Stakeholders and Strategic Responses in Pakistan”, UNEAC Asia Papers, No. 8.
} 
achieved little in mollifying opposition and it was the Rau Commission (1942) that provided the framework for allocating water between what was to become the provinces of Pakistan.

In this respect, the 1960 Indus Water Treaty was significant for inter-provincial rivalry within Pakistan, particularly between Punjab and Sindh. The Jhelum and Chenab have both drained into the Indus by the time they reach Sindh, meaning that Punjab maintained a greater degree of control over volume of water available to its lower riparian counterpart. Since all of the provinces of Western Pakistan had been amalgamated with the military take-over in 1958, these rivalries were largely ignored in negotiations, much to the chagrin of the Sindhis, who felt that their interests had been passed over in favour of those of the Punjab and have been ever since. ${ }^{25}$ Although further challenges to the validity of this earlier framework is evident from the Water Allocation and Rates Commission (1968 - otherwise known as the Akhter Hussain Commission) and the Fazle Akbar Committee (1970), neither had any influence in changing the status quo. ${ }^{26}$

The Water Apportionment Accords was negotiated between the four provinces of Pakistan in 1991, with a regulatory authority to supervise the implementation of its provisions, called the Indus River System Authority (IRSA), established in 1993. ${ }^{27}$ The purpose of this accord is to establish recognition of existing canals and apportion future supplies. This was done by dividing water on the basis of the previous seven years supply, which most suggested unduly favoured Punjab. ${ }^{28}$ The accord worked reasonably well until the first shortages occurred in 1994, at which point a new Water Sharing Agreement was negotiated. ${ }^{29}$ A new agreement was reached that shared water between the provinces according to the aggregate use of the previous seven years, a formula that Sindh

\footnotetext{
${ }^{25}$ H. Gazdar (2005).

${ }^{26}$ H. Mansoor (2002) “Water Wars: Sindh's struggle for control of the Indus" Himal, July.

${ }^{27}$ This information is taken from Pakistan Water Gateway, <www.waterinfo.net.pk>.

${ }^{28}$ Mansoor (2002).

${ }^{29}$ I. Shahzad (2002) “A Nation divided over water” Dawn March $18^{\text {th }}$.
} 
immediately dismissed as unjust and has been the basis for agitation and resentment ever since. $^{30}$

Resentment has also arisen within Balochistan among those who feel that the Sindh is not releasing adequate amounts of water. The disputes over water distribution have continued, with tensions particularly during the Rabi season when shortages of water are acute. A large bureaucratic system has developed to mediate decisions about water sharing but has thus far been largely unsuccessful in finding technical solutions to what are perceived within Pakistan to be political issues. ${ }^{31}$

\section{Bangladesh}

The economy of Bangladesh, the erstwhile East Pakistan, was reliant at partition from India in 1947, upon several industries that were fading in global importance, most notably jute. ${ }^{32}$ The period between the formation of Pakistan and independent Bangladesh in 1971 also served to exacerbate these problems, with East Pakistan having poor infrastructure and a lack of skilled manpower and capital. ${ }^{33}$ Initially, the Pakistani government favoured the domestic capitalist classes of west Pakistan. Indeed, it was not until the late 1960s that East Pakistan began to receive substantial assistance toward industrialisation, which was exacerbated by the fact that there was almost no east Pakistani capitalist class. ${ }^{34}$

With Independence in 1971, the Sheik Mujib Rahman-led Awami League (AL) government attempted to pursue a program of nationalisation and intervention-led economic growth. Again, this was done with little attention to the rural areas, which were dominated by a (jotedar) land-holding class. After Mujib's assassination in 1975, General Ziaur Rahman (hereafter Zia) under took a rapid reversal of Mujib's state-led policies. Since the majority

\footnotetext{
${ }^{30}$ Mansoor (2002).

31 The bureaucracy charged with dealing with these issues includes the following bodies: The Ministry of Water and Power, Wapda, Indus River System Authority, Technical Committee on Water Resources, National Assembly's Standing Committee, Senate Standing Committee and Federal Flood Committee, Council of Common Interests and the Inter-Provincial Coordination Committee.

${ }^{32}$ M. Khan “The Political Economy of Industrial Policy in Pakistan 1947-1971”, Working Paper, Department of Economics, SOAS, University of London.

${ }^{33}$ S. Kochanek (1996) “The Rise of Interest Politics in Bangladesh” Asian Survey, 36(7) (July): 708.

${ }^{34}$ Khan (n.d.).
} 
of beneficiaries of this system were large, family run business houses, the distorted liberalisation of this era set in place a patrimonial system that in the subsequent periods has seen greater direct and indirect influence of these dominant classes on the workings of politics. Thus accumulation has been to the almost complete detriment of the vast majority of the country's population, who remain among the poorest in the world. From 1978 onwards, the newly formed Bangladesh Nationalist Party (BNP) under Zia presided over a weak and fragmented opposition aided by support from these dominant classes. These groups were in return shielded from scrutiny over the increasing large revenues being gained from legal and illegal use of public resources. ${ }^{35}$

The system of kleptocracy accelerated during the almost decade long military rule of General Hussain M. Ershad (hereafter Ershad) from 1982 onwards. ${ }^{36}$ With little popular support for this process, Ershad nevertheless managed to sustain his rule by appeasing the multilateral donor community and enriching business elites. During the era of Khaleda Zia's BNP government (1991-1996) the Awami League (1996-2001) and the BNP the process of liberalisation again gained further momentum.

Bangladesh is a country with more than sufficient water but insufficient capacity to store the highly seasonal variation of rainfall, so that it periodically varies between acute shortages and over abundance, despite efforts to expand irrigation canals and embankments. Perhaps surprisingly, the division of water has not been as internally divisive between provincial entities in Bangladesh as it has been in other countries in the region.

In all three of these countries, then, the class interests of the polity have been a vital determinant of the kinds of development strategy followed, with a preference for the interest of the dominant classes only tempered when necessary by politically necessary inclusiveness in policy of other classes. The class structure has also impacted upon the

\footnotetext{
${ }^{35}$ F. Quadir (2000) "The political economy of pro-market reforms in Bangladesh: regime consolidation through economic liberalization?” Contemporary South Asia 9(2): 201.

${ }^{36}$ Although there were elections held in 1986 and 1988, it is widely believed that Ershad bribed opposition parties into standing in order to lend legitimacy to his rule. S. Kochanek (1993) Patron-Client Politics and Business in Bangladesh, Dhaka: University Press, pp. 226-227.
} 
structure of water resource policy. In some cases, this has been through an unwillingness to monitor the wasteful and inefficient use of water by industry. In other cases, it has been by supporting large landholders. In each case, it has meant that there remains a large section of the population - in both the rural and urban areas - who do not have adequate access to water for livelihoods or food security.

\section{Dams in South Asia}

A significant insight into the contours of the political economy of development in India and Pakistan is afforded by an examination of dams. Indeed, aside from the bilateral sharing of surface water, the other major, mostly intra-national, water controversy prevalent in South Asia has been the location and construction of dams. India, with approximately 4300 dams in 1994, can claim to one of the world's major builders of dams. ${ }^{37}$ Indeed, dams were one of the centrepieces of the Nehruvian strategy of planned industrialisation, along with the other 'temples' of modernisation, such as steel refineries and factories.

Critics of the reliance upon large-scale dams suggest that several factors render this strategy unsustainable and inequitable. The International Rivers Network (IRN), for example, highlights four areas of objection. Firstly, large dams are usually associated with large-scale displacement. The IRN suggests that large dams in India have displaced at least 42 million people, a disproportionately high number of them tribal people. Secondly, they note the environmental damage associated with clearing of forests and the impacts accompanying road-building, so that the building of the dam has a pronounced local effect. Thirdly, they highlight possible dangers arising from dams being built in areas of high seismic activity. Fourthly, critics question the long-term effectiveness of these dams on the basis that siltation will considerably reduce their expected capacity over time. ${ }^{38}$ The Tehri Dam, in Uttaranchal in the Indian Himalayas is the most emblematic of these campaigns.

The Tarbela Dam in Pakistan has also been criticised for the above failings. This is one of the world's most significant dams, providing nine percent of the Indus System's total

\footnotetext{
${ }^{37}$ Peter Bosshard (2004) 'World Bank: Lessons not learnt', $<$ http://www.sanctuaryasia.com/features/detailfeaturescategory.php?id=647\&catid=52>.

${ }^{38}$ Bosshard (2004).
} 
irrigation water and 28 percent of Pakistan's electric power. From the outset, the dam has been beset with problems, which led to a significant overrun of costs. At least 96000 people were displaced, of which 20000 have not been rehabilitated. Of those who were compensated, estimates suggest that the long delays meant that the compensation had devalued by half. There have also been indications of severe ecological impacts, with a loss of fish diversity and a significant salination. There is also enormous loss of forest cover, increased intrusion of seawater up the Indus, depletion of mangrove forests and sever flooding. The Tarbela has also exacerbated provincial rivalries, since most of the benefits of the project accrue to the Punjab, while most of the damage is borne by the Sindh. ${ }^{39}$

Indeed, this inter-provincial tension is evident in many dam projects in South Asia, precisely because the states that receive the greatest benefit from the dams are not always the same as those that have to compensate the losers. The Narmada Valley Development Project, which has now been in process for three decades, involves the construction of 30 large, 135 medium and 3000 small dams on the Narmada river and its tributaries. ${ }^{40}$ This scheme involves the governments of Gujarat, Madhya Pradesh and Maharastra. Although most of the costs, including rehabilitation and construction, will be borne by Madhya Pradesh, the state will benefit the least from the dam complex when it is finally finished. This has led to political disputes between the three states. Similarly, in Pakistan, the majority of the provinces have opposed the construction of the Kalabagh dam on the Indus. The political representatives of the provinces of Sindh, the NWFP and Baluchistan all argue that the construction of this dam serves only the interests of Punjab. ${ }^{41}$

\section{Water, Agriculture and Rural development}

The increasing disputes over the allocation of water in the region impacts significantly on food security. Agriculture remains the most significant factor in food security in rural areas

\footnotetext{
${ }^{39}$ All of the above figures are taken from 'The World Bank and Large Dams: Failure to Learn from History' $<$ http://www.environmentaldefense.org/documents/3011_Gambling_Dams.pdf $>$.

${ }^{40}$ L. Bavadam (2003) "Narmada Valley Project: Rising concerns", Frontline 20(12), $<$ http://www.frontlineonnet.com/fl2012/stories/20030620002404100.htm>.

41 "Pakistan: Focus on the dams dispute in Pakistan", $<$ http://www.irinnews.org/report.asp?ReportID=36592\&SelectRegion=Central_Asia\&SelectCountry=PAKIS TAN $>$.
} 
throughout South Asia, the development of which is intimately linked to the control of irrigation. While much of the agricultural growth in the 1950s and early 1960s came from an increase in net sown area, the improvements thereafter have come to a greater extent from changes in productivity as yields have increased for several major crops.

A changed agricultural strategy, based on higher usage of water and other inputs to increase productivity, began to become generalised in most South Asian countries in the mid-1960s. To supplement this, the dominant approach to rural development in the post-Independence period in South Asia has rested on supplying subsidised inputs to farmers, which it was hoped would rapidly increase agricultural production and thus reduce rural poverty. The spread of Green Revolution technology throughout South Asia was assisted by the supply of inputs through extension activities and complimentary infrastructure, as successive governments provided the means to build deep tubewells and extend canals through poverty alleviation plans. ${ }^{42}$

In the Indus basin, agricultural productivity initially increased rapidly as a consequence of the widespread adoption of Green Revolution technology, where many of the pilot programmes were pioneered. Shallow and deep tubewells and low lift irrigation pumps began to be sunk in this part of India in the 1950s and were adopted in (West) Pakistan in the 1960s and 1970s. The growth in groundwater complemented the already extensive canal system, which also increased. In the current era, almost 90 percent of Pakistan's most important primary products, including rice, wheat and cotton, come from the Sindh and Punjab provinces. Similarly, while India's agricultural base has become somewhat more spatially diversified over time Punjab and Haryana continue to be the most significant agricultural states.

In contrast, the Ganges region of South Asia experienced a long period of agricultural stagnation from the mid- colonial period. The populous Indian states of the Hindi belt (in central and western India), fed only by the Ganges system, have suffered from shortages of

\footnotetext{
${ }^{42}$ More details on poverty alleviation plans in South Asia can be found in S.R. Osmani (1999) "Social Security in South Asia", in E. Ahmad, J. Dreze, J. Hills \& A.K. Sen (eds.) Social Security in Developing Countries, New Delhi: Oxford University Press, Indian Edition), pp. 305- 355.
} 
water relative to the amount of cultivatable land. This has become particularly the case as population has increased. The Bengal delta, where the rivers of the Ganges basin drain into the ocean, is far better endowed with water resources than the part of the basin further to the west, although until recently this potential has failed to translate into agricultural growth. Agricultural growth remained stagnant in both East and West Bengal, from around 1860 until the mid-1980s. ${ }^{43}$

In examining the limitations of agricultural performance in Bengal (Bangladesh and West Bengal), work has been preoccupied with the question of why, with such favourable conditions, the region was slow to adopt Green Revolution technology. ${ }^{44}$ James Boyce's landmark study, examining the period up to the mid-1980s, argued that the inadequate control of irrigation water was 'the leading input' contributing to the region's continuing stagnation. ${ }^{45}$ He reasoned that institutional factors were also significant. In particular, the hierarchical nature of Bengal's agrarian structure led to an under-utilisation of labour and discouraged cooperation in increasing access to controlled water. Surface water was not adequately controlled and much of the flow remains seasonal, with monsoonal flooding followed by dry season shortages.

\section{The impact of the expansion of groundwater}

While the initial stages of the Green Revolution were built around supplementing the already existing canal system, the latter stages are more associated with a notable increase in groundwater extraction throughout previously undeveloped parts of South Asia (particularly in the Ganges basin). This development has been less visible and contentious

\footnotetext{
${ }^{43}$ Rogaly, B., B. Harriss-White \& S. Bose (eds) (1999) Sonar Bangla? Agricultural Growth and Agrarian Change in West Bengal and Bangladesh, Dhaka: University Press Limited.

${ }^{44}$ For example see V. Rawal (1999) Irrigation Development in West Bengal 1977-78 to 1995-96 Unpublished PhD thesis, Indira Gandhi Institute of Development Research, Mumbai; V. Rawal \& M. Swaminathan (1998) "Changing trajectories: agricultural growth in West Bengal, 1950 to 1996", Economic and Political Weekly, 33(40): 2595-2602; Rogaly et al. (1999).

${ }^{45}$ The experience of South Asian countries largely confirm the hypothesis of Ishikawa (1967), who, in studying agricultural change in various other Asian countries, found that irrigation was the 'leading input' in the first three of his four stages of agricultural contributing to growth In doing so, he distinguished four different stages of productivity. While irrigation is the leading input in the first three stages of this transition, by the fourth stage fertiliser, better seeds and improved techniques become the 'combined leading input'. Inputs such as labour, fertilizer and seeds are also all important in influencing these changes. J.K. Boyce (1987) Agrarian impasse in Bengal: institutional constraints to technological change, Oxford; New York: Oxford University Press, p. 33.
} 
than the state-supported development of surface water in the post-colonial period, since much of the increase has occurred through privately owned, small-scale tubewells. The development of groundwater resources is often heralded as more accessible than surface water irrigation, since it is less capital intensive and is less restricted by topography than canal development.

India is perhaps the most dramatic example in South Asia of the recent rapid expansion of groundwater. A recent study suggested that 60 percent of the country's irrigated area now comes from groundwater. In Bangladesh, groundwater accounts for 75 percent of the total water use and 95 percent of population's water for domestic use comes from groundwater. Pakistan has seen significant development of groundwater resources in the past 30 years. Large capacity tubewells were installed by the state and this was a spur to the proliferation of smaller private tubewells. ${ }^{46}$ In Pakistan, most of the groundwater development (70 percent) is also in areas where canals are prevalent, which is evidence of the concentrated nature of agriculture, confined as it mostly is to the Punjab and Sindh provinces. Estimates suggest that between 1972 and 1997 the contribution of groundwater to irrigated agriculture in Pakistan nearly doubled and the number of irrigation tubewells increased by almost 500 percent from 1970 to $1996 .^{47}$

The effects of the adoption of the Green Revolution strategy have been mixed. In the short term, there have definitely been productivity improvements and increasing yields. India and Pakistan have achieved self-sufficiency in food grain production, which represents a remarkable feat given the dire predictions of Malthusian doom accompanying the regions rapid population growth. However, this is far from uniform across regions and the broader, long-term social and environmental effects of the Green Revolution are contentious. There is now considerable evidence that the growth of groundwater expansion is associated with resource over-exploitation, particularly in the heavily populated western and central areas

\footnotetext{
${ }^{46}$ All of these figures are from M. Akhtar Bhatti (2002) "Groundwater management in South Asia - A regional initiative" (Member, South Asia Coordinating Committee for WWE 3 and Member, Steering Committee of Pakistan Water Partnership - PWP) Presented at International Network of Basin Organisations, General Assembly Quebec City - Quebec - Canada, May 28-29-30, 2002.

${ }^{47}$ World Commission on Dams (2000) Pakistan.
} 
of the Gangetic belt, which are poorly served by canal irrigation. ${ }^{48}$ According to World Bank reports, 38 percent of Pakistan's irrigated land area is waterlogged, and soil salinity has caused a 25 percent reduction in the production of Pakistan's major crops. ${ }^{49}$ The lack of coordination among users of groundwater heralds a classic 'tragedy of the commons' scenario. Evidence across South Asia suggests problems with the growing salinisation of aquifiers (seawater intrusion) and arsenic and chromium pollution.

The increased use of groundwater has also spurred a growing local market in water-selling. For example, 88 percent of pump owners in Bangladesh reported selling water, with 60 percent in Nepal and 48 percent in West Bengal. ${ }^{50}$ Some have argued that this increased marketisation of water will slow the overexploitation of groundwater. However, early micro-scale case studies refute this optimism, as exploitation continues apace. These studies also suggest that the growth of water markets is reinforcing inequalities in the agrarian structure, with those having ownership of pumps generally drawn from the rural elite. There is evidence that the pattern of ownership has broadened in some places, although not as far as the landless or marginal farmers. While some of these transactions involve money, there are also many examples where they involve interlinkages with credit or labour, thus further reinforcing class relationships within the agrarian structure. ${ }^{51}$

An evolving 'tragedy of the commons', leading to ecological problems and increasing inequality, is not a problem unique to water resources. Other common pool resources, such as forests, have experienced similar problems in much of South Asia. However, in the forestry sector, co-management schemes, involving community groups in the management of resources in collaboration with the state, have enjoyed notable success in many parts of

\footnotetext{
${ }^{48}$ For details see Vaidyanathan, A. (2001) Water Resource Management: Institutions and Irrigation Development in India, New Delhi: Oxford University Press, Paperback Edition.

${ }^{49}$ Bosshard (2004).

${ }^{50}$ Quoted in Mukherjee, A. (2004) “Groundwater Markets in Ganga-Meghna-Brahmaputra Basin: Theory and Evidence", Economic and Political Weekly, July.

${ }^{51}$ See Hanan G Jacoby, Rinku Murgai \& Saeed Ur Rehman (2004) "Monopoly Power and Distribution in Fragmented Markets: The Case of Groundwater", The Review of Economic Studies 71(248); M. Ali \& D. Byerlee (2002) "Productivity growth and resource degradation in Pakistan's Punjab: A decomposition analysis", Economic Development and Cultural Change 50(4).
} 
South Asia in slowing resource degradation. ${ }^{52}$ There has been less activity in promoting schemes for the co-management of groundwater, although this is obviously an area that may warrant further effort in the future.

While the social and ecological impacts of the Green Revolution in South Asia are well known outside the region, the political consequences have received less attention. From the 1970s onwards, farmer's movements have become an increasing force in Indian and Pakistani politics. There is considerable debate about the class representation of the New Farmer's Movement in India, although the main interests represented are large and medium farmers. ${ }^{53}$ Similar movements have developed in Pakistan. In the Pakistani province of Punjab the main class composition is reported to be large and middle peasants, whereas in the Sindh it covers all classes to a much greater degree. ${ }^{54}$ The main platform of these movements has been to lobby for subsidised cultivation inputs and assured minimum prices for their produce. This has assisted the over exploitation of resources like water since electricity and diesel technology has remained relatively inexpensive.

Increased demands from groundwater have led to new forms of contestation. For example, localised and pre-existing inequalities within the agrarian structure impact upon the distribution and usage of tubewells. Individual private actors drawing upon common property, in this case aquifiers, in an unregulated fashion, are a cause of coordination issues. Farmers' movements have a strong presence in provincial and national-level politics in both Pakistan and India. The demands for cheaper, heavily subsidised cultivation inputs (fertiliser, pesticides and electricity) by these farmers movements has contributed to the largely unregulated over-exploitation of groundwater resources.

\section{Conclusion}

The paper has outlined some of the major dimensions of the contestation over water in the South Asian countries of Pakistan, India and Bangladesh. The processes involved in

\footnotetext{
${ }^{52}$ Kothari, A., N. Pathak, R.V. Anuradha, \& B. Taneja (eds.) Communities and Conservation: Natural Resource Management in South and Central Asia, New Delhi: Sage.

${ }^{53}$ Banaji, J. (1994) “The farmers' movements - a critique of conservative rural coalitions" Journal of Peasant Studies 21(3/4): 228-245.

${ }^{54}$ Gazdar (2005).
} 
regulating this contestation have at various times strained the relationships between all three countries. There are also significant clashes over water within these countries. These take the form of both inter-state and inter-class contestation, which are exemplified by the emphasis on large dams. Agricultural intensification has significantly increased the use of water. The increased use of groundwater has made the benefits of the green revolution far more accessible to a greater number of people than the previous system that was overly reliant upon seasonal flow from canals and rivers. However, there have been significant ecological and social costs associated with this process, which suggests that the current pattern is unsustainable.

While market-based solutions for water-selling may in theory assist in reducing degradation of water resources by assigning private property rights to usage, the over-exploitation of groundwater will not be adequately regulated unless a greater emphasis is placed upon community based resource management solutions. Besides, market-based solutions exclude the asset-poor, not least the many landless and those others who are not cultivators. Whether there is adequate political will to alter the current scenario will be one of the factors defining future contestations over water in the region.

\section{References}

The Hindu Businessline (8 January 2005) "Baglihar project talks fail; Pak threatens to move World Bank".

Hindustan Times (5 February 2006) "Is Baglihar turning into a white elephant?”.

Hindustan Times (28 February 2006) "Kashmir gets special aid for development, power".

Irin news report (n.d.) "Pakistan: Focus on the dams dispute in Pakistan" $<$ http://www.irinnews.org/report.asp?ReportID=36592\&SelectRegion=Central_Asia $\&$ SelectCountry $=$ PAKISTAN $>$.

Environmental Defense (n.d.) "The World Bank and Large Dams: Failure to Learn from History" $<$ http://www.environmentaldefense.org/documents/3011_Gambling_Dams.pdf $>$.

The Hindu Businessline (9 March 2005) "World Bank may help resolve Baglihar row".

Akhtar Bhatti, M. (2002) "Groundwater management in South Asia - A regional initiative" (Member, South Asia Coordinating Committee for WWE 3 and Member, Steering Committee of Pakistan Water Partnership - PWP) Presented at International Network of Basin Organisations, General Assembly Quebec City, Quebec, Canada, May 28 $30,2002$. 
Ali, I. (2005) "Business, Stakeholders and Strategic Responses in Pakistan', UNEAC Asia Papers, No. 8.

_ (2004) "Historical Impacts on Political Economy in Pakistan" Asian Journal of Management Cases, 1(2).

Ali, M \& Byerlee, D. (2002) "Productivity growth and resource degradation in Pakistan's Punjab: A decomposition analysis", Economic Development and Cultural Change, 50(4).

Anwar, S. (1996) “Opposition slams Bangladesh water deal with India” Reuters News $14^{\text {th }}$ December.

Banaji, J. (1994) "The farmers' movements - a critique of conservative rural coalitions" Journal of Peasant Studies, 21(3/4): 228-245.

Bandyopadhyay, J. (1995) "Water Management in the Ganges-Brahmaputra Basin: Emerging Challenges for the 21st Century", Water Resources Development, Vol. 11(4): 411-442.

Bardhan, P. (1984) The Political Economy of Development in India. Delhi: Oxford University Press.

Bosshard, P. (2004) "World Bank: Lessons not learnt", accessed at $<$ http://www.sanctuaryasia.com/features/detailfeaturescategory.php?id=647\& catid $=5$ $2>$.

Boyce, J.K. (1987) Agrarian impasse in Bengal: institutional constraints to technological change. Oxford, New York: Oxford University Press.

Brichieri-Colombi, S. \& Bradnock, R.W. (2003) "Geopolitics, water and development in South Asia: cooperative development in the Ganges-Brahmaputra delta", The Geographical Journal, March.

Chakrabarti A. \& Cullenberg, S. (2003) Transition and development in India. New York and London: Routledge.

Corbridge, S. \& Harriss, J. (2000) Reinventing India: Liberalization, Hindu Nationalism and Popular Democracy. Cambridge: Polity Press.

Gazdar, H. (26 February 2005) "Baglihar and Politics of Water", Economic and Political Weekly.

Haq, K. (2003) Human Development in South Asia 2002: Agriculture and Rural Development. Mahub ul Haq Human Development Centre, Oxford University Press.

Hossain, I. (1998) "Bangladesh-India Relations: The Ganges Water-Sharing Treaty and Beyond", Asian Affairs, 25(4).

Jacoby, H.G., Murgai, R. \& Rehman, S.U. (2004) "Monopoly Power and Distribution in Fragmented Markets: The Case of Groundwater", The Review of Economic Studies, 71(248).

Kaviraj, S. (1998) “A Critique of the Passive Revolution” in Chatterjee, P. (ed.) State and Politics in India. Delhi: Oxford University Press. 
Khan, M. (n.d.) "The Political Economy of Industrial Policy in Pakistan 1947-1971", Working Paper, Department of Economics, SOAS, University of London.

Kochanek, S. (1993) Patron-Client Politics and Business in Bangladesh. Dhaka: University Press.

_ (1996) "The Rise of Interest Politics in Bangladesh" Asian Survey, 36(7), July.

Kothari, A., N. Pathak, N., Anuradha, R.V. \& Taneja, B. (eds.) Communities and Conservation: Natural Resource Management in South and Central Asia. New Delhi: Sage.

Mansoor, H. (2002) “Water Wars: Sindh's struggle for control of the Indus” Himal, July.

Mukherjee, A. (2004) "Groundwater Markets in Ganga-Meghna-Brahmaputra Basin: Theory and Evidence", Economic and Political Weekly, July.

Nations, R. (1971) "The Economic Structure of Pakistan: Class and Colony", New Left Review, No. 68, July-August.

Noorani, A.G. (2002) “A treaty to keep”, Frontline 19(8), April 13 - 26.

Osmani, S.R. (1999) "Social Security in South Asia", in Ahmad, E., Dreze, J., Hills, J. \& Sen, A.K. (eds.) Social Security in Developing Countries. New Delhi: Oxford University Press, Indian Edition.

Quadir, F. (2000) "The political economy of pro-market reforms in Bangladesh: regime consolidation through economic liberalization?", Contemporary South Asia, 9(2).

Rawal, V. \& Swaminathan, M. (1998) "Changing trajectories: agricultural growth in West Bengal, 1950 to 1996", Economic and Political Weekly, 33(40).

Rawal, V. (1999) Irrigation Development in West Bengal 1977-78 to 1995-96, unpublished $\mathrm{PhD}$ thesis. Indira Gandhi Institute of Development Research, Mumbai.

Rogaly, B., Harriss-White, B. \& Bose, S. (eds.) (1999) Sonar Bangla? Agricultural Growth and Agrarian Change in West Bengal and Bangladesh. Dhaka: University Press Limited.

Shahzad, I. (2002) “A Nation divided over water”, Dawn $18^{\text {th }}$ March.

Vaidyanathan, A. (2001) Water Resource Management: Institutions and Irrigation Development in India. New Delhi: Oxford University Press, Paperback Edition.

WCD Case Studies (2000) Tarbela Dam and related aspects of the Indus River Basin Pakistan Final Draft Report. World Commission on Dams.

World Commission on Dams (2000) Pakistan: The Tarbela Dam and Indus River Basin Final Paper, accessed at <http://www.dams.org/kbase/studies/pk/pk_exec.htm>.

World Commission on Dams and Asianics (1999) Review of the Performance and Development Effectiveness of Tarbela Dam in The Context of the Indus Basin Scoping Report (Islamabad and South Africa).

Wright, D. (2002) “The BJP and Bangladesh” South Asia vol. XXV. 